\title{
STUDI PENERAPAN SISTEM MANAJEMEN KESELAMATAN DAN KESEHATAN KERJA DI PT. MUARA KAYU SENGON DESA MARGASANA KECAMATAN JATILAWANG KABUPATEN BANYUMAS TAHUN 2016
}

\author{
Dany Rahma Saputra ${ }^{1)}$, Yulianto ${ }^{2)}$ \\ Jurusan Kesehatan Lingkungan, Politeknik Kesehatan Kemenkes Semarang, \\ Jl. Raya Baturaden KM 12 Purwokerto, Indonesia
}

\begin{abstract}
Abstrak
PT Muara Kayu Sengon sebagai salah satu industri yang tidak terlepas dari aktivitas yang melibatkan tenaga kerja, alat, metode, biaya, dan material serta waktu yang cukup besar. Oleh karena itu, dibutuhkan sistem manajemen keselamatan dan kesehatan kerja yang sesuai dengan PP No. 50 tahun 2012. Penelitian ini bertujuan Untuk mengetahui keberhasilan Pabrik PT. Muara Kayu Sengon menerapkan Sistem Manajemen Keselamatan dan Kesehatan Kerja (SMK3) yang disesuaikan dengan PP No. 50 tahun 2012.Jenis penelitian ini termasuk penelitian deskriptif dan dilakukan dengan pengumpulan data lapangan dengan checklist dan di sesuiakan dengan PP No. 50 Tahun 2012. Hasil PenelitianPT. Muara Kayu Sengon termasuk dalam kategori Kurang dengan hasil 23,43\% dikarenakan belum menerapkan Sistem Manajemen Keselamatan dan Kesehatan Kerja (SMK3) dengan baik yang sesuai dengan PP No. 50 Tahun 2012. Kesimpulansistem manajemen keselamatan dan kesehatan pada PT. Muara Kayu Sengon belum semua kriteria diterapkan dan termasuk dalam kategori kurang dengan hasil 23,43. PT, Muara Kayu Sengon disarankan agar mempunyai ahli K3 agar pelaksanaan dan pemantauan SMK3 dapat berjalan dengan efektif.
\end{abstract}

Kata kunci : SMK3, Industri Kayu

\begin{abstract}
Study of application of occupational healt and safety management PT Muara Kayu Sengon Margasana village Jatilawang sub district district Banyumas Year 2016. PT Muara Kayu Sengon as one an industry that cannot be separated from the activity involving labor, an instrument, method, costs, and materials and considerable time.Therefore, the required occupational healt and safety management ( SMK3 ) in accordance with the PP. 50 in 2012.This study aims toknow the success of PT. Muara Kayu Sengon banyumas in applying occupational healt and safety management ( SMK3 ) accordance with PP no. 50 in 2012. This study is based on a descriptive research and accordance with PP no. 50 in 2012.The results of the study showed pt.Muara Kayu Sengon included in a category less with the results of 23,43 \% because not yet applicated occupational healt and safety management ( SMK3 )are god in accordance with PP no. 50 in 2012.The conclusions of this research, occupational healt and safety management at PT. Muara Kayu Sengon 23.43\% have not applied and included in the category of less. Based on PP No. 50 in 2012 PT Muara Kayu Sengon it is recommended that has experts in order that the implementation and monitoring of the K3 (SMK3) countries can run effectively
\end{abstract}

Keywords : Occupational healt and safety management, Wood Industry

\section{PENDAhuluan}

Keselamatan dan kesehatan kerja berperan penting bagi para tenaga kerja, emaka untuk mengantisipasi dan mengurangi angka kecelakaan kerja dan penyakit akibat kerja juga melindungi tenaga kerja, maka pemerintah mengeluarkan Undang-Undang No. 13 Tahun 2003 Pasal 86 Ayat 1 dan 2 yang menyatakan "Setiap pekerja/buruh mempunayi hak untuk memperoleh perlindungan atas keselamatan dan kesehatan kerja; moral dan kesusilaan; dan perlakuan yang sesuai dengan harkat dan martabat manusia serta nilai-nilai agama.

1) Email : danykhoi0606@gmail.com

2) Email : yulianto_61@yahoo.com
Berdasarkan undang-undang No.13 Tahun 2003 Pasal 86 Ayat 1 dan pasal 2, maka perusahaan harus mempersiapkan sarana dan prasarana sebagai upaya pencegahan kecelakaan kerja dan program-program yang dapat mengurangi angka kecelakaan kerja di perusahaan. Salah satu programnya adalah program keselamatan dan kesehatan kerja para tenaga kerja. Program ini dibuat berdasarkan kegiatan produksi yang dilakukan oleh perusahaan tersebut..

Masalah-masalah keselamatan dan kesehatan kerja tidak lepas dari kegiatan dalam industri secara keseluruhan, maka pola-pola yang harus dikembangkan di dalam penanganan bidang 
keselamatan dan kesehatan kerja dan pengadaan pengendalian potensi bahaya harus mengikuti pendekatan sistem yaitu dengan menerapkan Sistem Manajemen Keselamatan dan Kesehatan Kerja (SMK3). Perbuatan tidak aman (unsafe act)maupun keadaan yang tidak aman15(unsafe condition) berakarlebih dalam daripada kecelakaan yang terlihat atau teralami. Seandainya manajemen keselamatan dan kesehatan kerja mengingatkan sedini mungkin mengenai faktor bahaya dan risiko kecelakaan kerja serta mewajibkan penggunaan alat pelindung yang sesuai dengan potensi bahaya yang ada di perusahaan maka para pekerja pun akan waspada pada saat berada di lokasi berbahaya dan beresiko kecelakaan kerja tersebut. Jadi, dapat disimpulkan bahwa kecelakaan kerja yang terjadi berasal dari Sistem Manajemen Keselamatan dan Kesehatan Kerja (SMK3) yang tidak dilakukan dan diterapkan dengan baik. Tujuannya adalah untuk mengetahui penerapan SMK3 di PT Muara Kayu Sengon.

\section{BAHAN DAN METODE}

Penelitian ini dilaksanakan di pabrik kayu PT. Muara Kayu Sengon yang bertempat di desa Margasana Kecamatan Jatilawang kabupaten Banyumas.

Subyek dalam penelitian ini adalah pihak-pihak yang berwenang dalam penerapan SMK3 di perusahaan, dan orang-orang yang berada di dalam ruangan maupun di luar ruangan dalam kegiatan yang dilakukan di perusahaan.

Analisis data menggunakan analisis deskriptif yaitu membandingkan kenyataan di lapangan atau hasil pemeriksaan dengan teori serta standar yang ada.

\section{III.HASIL DAN PEMBAHASAN}

Dari checklist yang terdapat pada PP No. 50 Tahun 2012 PT. Muara Kayu Sengon termasuk kedalam perusahaan atau pabrik tahap awal yang mencakup 64 kriteria yang ada dalam PP No. 50 Tahun 2012 karena PT. Muara Kayu Sengon belum menerapkan SMK3 di dalam Perusahaan tersebut. Adapun penjelasan dari checklist yang mencakup 12 elemen adalah sebagai berikut :

a. Pembangunan dan Pemeliharaan Komitmen

Dari hasil penilaian melalui checklist yang telah disesuaikan dengan PP. No. 50 taun 2012, maka pada kriteria pembangunan dan pemeliharaan komitmen yang terdiri dari 14 kriteria 2 diantaranya sudah memenuhi syarat penilaian yang dilakukan, dalam penilaian ini PT. Muara Kayu Sengon masuk dalam kategori kurang dengan hasil 14,28\%.

Perusahaan belum menerapkan SMK3 sesuai dengan peraturan yang berlaku, tetapi pihak perusahaan sudah merencenakan untuk menerapkan SMK3 yang sesuai dengan peraturan yang berlaku yaitu Peraturan Pemerintah No. 50 Tahun 2012.

\section{Kriteria yang sesuai}

1.1.1 Terdapat kebijakan K3 yang tertulis bertanggal, ditandatangani oleh pengusaha atau pengurus, secara jelas menyatakan tujuan dan sasaran K3 serta komitmen K3.

1.2.5 Petugas yang bertanggung jawab untuk penanganan keadaan darurat telah ditetapkan dan mendapatkan pelatihan.

\section{Kriteria yang tidak sesuai}

1.1.3 Perusahaan mengkomunikasikan, kebijakan, K3 kepada seluruh tenaga kerja, tamu, kontraktor, pelanggan, dan pemasok dengan tata cara yang tepat

1.2.2 Penunjukan penanggung jawab K3 harus sesuai peraturan perundang-undangan

1.2.4 Pengusaha atau pengurus bertanggung jawab secara penuh untuk menjamin pelaksanaan SKMK3

1.3.3 Pengurus harus meninjau ulang pelaksanaan SMK3 secara berkala untuk menilai kesesuaian dan efektivitas SMK3

1.4.1 Keterlibatan dan penjadwalan konsultasi tenaga kerja dengan wakil perusahaan didokumentasikan dan disebarluaskan ke seluruh tenaga kerja.

1.4.3 Perusahaan telah membentuk P2K3 sesuai dengan peraturan perundang-undangan

1.4.4 Ketua P2K3 adalah pimpinan puncak atau pengurus

1.4.5 Sekretaris P2K3 adalah ahli K3 sesuai dengan peraturan perundang-undangan

1.4.6 P2K3 menitikberatkan kegiatan pada pengembangan kebijakan dan prosedur mengendalikan risiko

1.4.7 Susunan pengurus P2K3 didokumentasikan dan diinformasikan kepada tenaga kerja

1.4.8 P2K3 mengadakan pertemuan secara teratur dan hasilnya disebarluaskan di tempat kerja

1.4.9 P2K3 melaporkan kegiatannya secara teratur sesuai dengan peraturan perundangundangan.

\section{Pembahasan}

1. Perusahaan belum mengkomunikasikan kebijakan K3 kepada seluruh karyawan. Menurut PP No. 50 tahun 2012, perusahaan harus mengkomunikasikan kebijakan K3 kepada seluruh tenaga kerja, tamu, kontraktor, pelanggan, dan pemasok dengan tata cara yang tepat. Sebaiknya perusahaan mengadakan breafing sebelum melakukan pekerjaan dan menyampaikan kebijakan K3 dan pentingnya K3 tersebut agar lebih efisien

2. Tanggung jawab dan wewenang untuk bertindakBelum semua personil yang bertanggung jawab untuk melakukan 
pelaporan tindakan kritis, pelaporan dilakukan dengan kesadaran dari pekerja tanpa ada yang bertanggung jawab. Menurut PP No. 50 tahun 2012, tanggung jawab di berikan kepada personil - yang mengambil tindakan tindakan pada saat kritis, yaitu :

- Melaporkan kepada semua personil yang terkait

- Menyebarluaskan dan mendokumentasikan Sebaiknya perusahaan menunjuk seorang petugas yang bertanggung jawab sepenuhnya apabila terjadi kecelakaan untuk segera melakukan pelaporan dan mendokumentasikannya, agar tindakan penanggulangan bisa berjalan dengan efektif dan cepat tanggap.

3. Perusahaan belum memiliki ahli K3, petugas yang bertanggung jawab terhadap K3 memiliki pekerjaan ganda pada perusahaan. Menurut PP No. 50 tahun 2012, penunjukan dan penanggung jawab K3 harus sesuai dengan peraturan perundangan yang memiliki kualifikasi yaitu ahli K3. Sebaiknya perusahaan mempekerjakan ahli K3 yang memiliki dasar pendidikan tentang $\mathrm{K} 3$ dan memenuhi kriteria seorang ahli K3.

4. Belum terbentuknya organisasi P2K3 sehingga kegiatan k3 belum berjalan dalam perusahaan, sebaiknya perusahaan membentuk organisasi P2K3 sehingga kegiatan K3 dalam perusahaan dapat berjalan dengan baik dan sebagai mana mestinya yang duatur dalam PP No. 50 tahun 2012. Sebaiknya di bentuk organisasi P2K3 untuk menangani kegiatan SMK3 di perusahaan.

5. Orang yang sementara mengurusi K3 belum ahli dalam bidang K3 sehingga bagian K3 tidak terlalu di perhatikan oleh perusahaan. Sebaiknya perusahaan merekrut ahli k3 untukmengatur masalah $\mathrm{k} 3$ di perusahaan.

b. Pembuatan dan Pendokumentasian Rencana K3

Dari hasil penilaian melalui checklist yang telah disesuaikan dengan PP. No. 50 taun 2012, maka pada kriteria Pembuatan dan Pendokumentasian Rencana K3 yang terdiri dari 2 kriteria dan belum ada yang memenuhi syarat penilaian yang dilakukan, dalam penilaian ini PT. Muara Kayu Sengon masuk dalam kategori kurang dengan hasil $0 \%$

Perusahaan belum membuat dan mendokumentasikan rencana $\mathrm{k} 3$,hal ini disebabkan karena perusahaan belum melaksanakan SMK3 yang sesuai dengan PP No. 50 Tahun 2012.

\section{Kriteria yang sesuai}

Belum ada kriteria yang sesuai

\section{Kriteria yang tidak sesuai}

2.1.1 Terdapat prosedur terdokumentasi untuk identifikasi potensi bahaya, penelitian, dan pengendalian risiko K3
2.4.1 Informasi yang dibutuhkan mengenai kegiatan K3 disebarluaskan secara sistematis kepada seluruh tenaga kerja, tamu, kontraktor, pelanggan, dan pemasok.

\section{Pembahasan}

1. Perusahaan belum menerapkan pembuatan rencana $\mathrm{k} 3$ yang di gunakan untuk manual K3, belum adanya kegiatan identifikasi bahaya, penilaian, dan pengendalian resiko k3 sebagai rencana strategi k3 yang dilakukan oleh petugas yang berkompeten di bidang tersebut. Sebaiknya perusahaan melakukan kegiatan identifikasi bahaya, penilaian, dan pengendalian resiko k3 yang ada di perusahaan dan dilakukan oleh ahli k3.

2. Manual SMK3 masih sulit di peroleh oleh semua personil dalam perusahaan. Menurut PP No. 50 tahun 2012 manual SMK3 harus mudah di dapat oleh semua personil dalam perusahaan, menyediakan dalam jumlah yang cukup dan menempatkannya pada tempat yang mudah di capai. Sebaiknya manual SMK3 disediakan secara merata kepada seluruh karyawan bisa dalam bentuk brosur atau selebaran lain.

3. Belum terselenggarakannya penyebaran informasi tentang kegiatan dan masalah keselamatan kerja belum di sebarluaskan secara sistematis kepada seluruh tenaga kerja perusahaan, tamu kontraktor, pelanggan, dan pemasok. Sebaiknya penyebaran infoemasi lebih baik penyebarannya misal dengan menggunakan brosur atau leaflet yang di bagika kepada seluruh karyawan perusahaan agar karyawan perusahaan juga dapat mendapat informasi k3.

c. Peninjauan Ulang Desain dan Kontrak

Dari hasil penilaian melalui checklist yang telah disesuaikan dengan PP. No. 50 taun 2012, maka pada kriteria Peninjauan Ulang Desain dan K3 yang terdiri dari 2 kriteria dan belum ada yang memenuhi syarat penilaian, dalam penilaian ini PT. Muara Kayu Sengon masuk dalam kategori kurang dengan hasil $0 \%$

Perusahaan masih belum melakukan Peninjauan Ulang Desain Dan Kontrak dalam bidang SMK3 karena perusahaan belum menerapkan SMK3.

Kriteria yang sesuai

Belum ada kriteria yang sesuai

\section{Kriteria yang tidak sesuai}

3.1.1 Prosedur yang terdokumentasi mempertimbangkan identifikasi potensi bahaya, penilaian, dan pengendalian risiko yang dilakukan pada tahap perancangan dan modifikasi

3.2.2 Identifikasi bahaya dan penilaian risiko dilakukan pada tinjauan kontrak oleh petugas yang berkompeten.

Pembahasan 
1. Belum adanya dokumen tertulis berupa prosedur perancangan yang didalamnya ada identifikasi aspek K3.yang sudah di atur dalam PP No. 50 Tahun 2012. Sebaiknya dibuat dokumen berupa prosedur perancangan untuk mengidentifikasi resiko k3 yangada di perusahaan.

2. Belum adanya petugas yang berkompeten untuk menangani masalah $\mathrm{k} 3$ yang ada di dalam perusahaan. Sebaiknya perusahaan mempekerjakan ahli k3 menangani masalah k3 dan memverifikasi perencanaan k3 di perusahaan.

d. Pengendalian Dokumen

Dari hasil penilaian melalui checklist yang telah disesuaikan dengan PP. No. 50 taun 2012, maka pada kriteria Pengendalian Dokumen K3 yang terdiri dari 1 kriteria dan belum ada yang memenuhi syarat penilaian yang dilakukan, dalam penilaian ini PT. Muara Kayu Sengon masuk dalam kategori kurang dengan hasil $0 \%$

Perusahaan sudah mulai melakukan pengendalian dokumen yang terkait dengan kegiatan yang dilakukan perusahaan, tetapi masih belum keseluruhan dokumen.

\section{Kriteria yang sesuai}

Belum ada kriteria yang sesuai

\section{Kriteria yang tidak sesuai}

4.1.1 Dokumen K3 Mempunyai identifikasi status, wewenang, tanggal pengeluaran dan tanggal modifikasi.

\section{Pembahasan}

1. Belum adanya sistem perubahan dokumen yang jelas dan alasan terjadinya perubahan tidak tertera pada dokumen. Sebaiknya perubahan dokumen disertakan dengan alasan terjadinya perubahan serta di lampirkan dalam dokumen yang baru tentang alasan tersebut agar informasi lebih mudah di terima.

2. Belum terdapat prosedur pengendalian dokumen atau daftar seluruh dokumen yang mencantumkan status dari setiap dokumen tersebut sebagai upaya untuk mencegah penggunaan dokumen yang sudah usang. Sebaiknya penataan dokumen lebih di perhatikan dengan menempatkan dokumen yang baru terpisah dengan dokumen yang sudah usang, agar tidak menimbulkan kekeliruan kelak.

\section{e. Pembelian}

Dari hasil penilaian melalui checklist yang telah disesuaikan dengan PP. No. 50 taun 2012, maka pada kriteria Pembelian yang terdiri dari 3 kriteria, 3 kriteria sudah tersebut memenuhi syarat penilaian yang dilakukan, dalam penilaian ini PT. Muara Kayu Sengon masuk dalam kategori baik dengan hasil $100 \%$.

PT. Muara Kayu Sengon telah memiliki prosedur pembelian yang terdokumentasi namun dokumen bersifat rahasia, sehingga data yang bisa di ambil sangat terbatas.

\section{Kriteria yang sesuai}

5.1.1 Terdapat prosedur yang terdokumentasi yang dapat menjamin bahwa spesifikasi teknik dan informasi lain yang relevan dengan K3 telah diperiksa sebelum keputusan untuk membeli.

5.1.2 Spesifikasi pembelian untuk setiap sarana produksi, zat kimia atau jasa harus dilengkapi spesifikasi yang sesuai dengan persyaratan peraturan perundang-undangan dan standar K3.

5.2.1 Barang dan jasa yang dibeli diperiksa kesesuaiannya dengan spesifikasi pembelian.

\section{Kriteria yang tidak sesuai}

Tidak ada kriteria yang tidak sesuai.

\section{Pembahasan}

1. Belum adanya konsultasi dengan pekerja yang kompeten terhadap keputusan pembelian produk yang dilakukan untuk ketepat gunaan pemakaian produk yang dicantumkan dalam spesifikasi pembelian dan diinformasikan kepada tenaga kerja yang menggunakannya. Sebaiknya dilakukan konsultasi kepada pekerja yang berkonpeten agar pembelian produk menjadi tepat dan diinformasikan kepada pekerja yang menggunakannya.

2. Tidak adanya identifikasi produk di seluruh tahapan produksi dan instalasi.sebaiknya di adakan identifikasi produk agar tidak menimbulkan masalah k3.

f. Penerapan Keamanan Bekerja Berdasarkan SMK3

Dari hasil penilaian melalui checklist yang telah disesuaikan dengan PP. No. 50 taun 2012, pada kriteria Penerapan Keamanan Bekerja Berdasarkan SMK3 yang terdiri dari 22 kriteria, 8 diantaranya sudah memenuhi syarat penilaian tersebut, dalam penilaian ini PT. Muara Kayu Sengon masuk kategori kurang dengan hasil 36,36 $\%$.

Penerapan keamanan bekerja pada PT. Muara Kayu Sengon yang telah di laksanakan adalah :

1. Keamanan konstruksi bangunan belum sepenuhnya terpelihara dengan baik, karena masih terdapat beberapa bangunan yang mulai rusak.

2. Keamanan pekerja, masih di temukannya beberapa pekerja yang enggan menggunakan APD.

3. Keamanan pencegahan dan penaggulangan terhadap bahaya kebakaran termasuk akses untuk evakuasi / pengungsian.

4. Keamanan pengguanaan alat, cara pengoperasian sarana dan proses produksi belum di lakukan oleh karyawan yang berpengalaman. 
Kriteria yang sesuai

6.2.1 Dilakukan pengawasan untuk menjamin bahwa setiap pekerjaan dilaksanakan dengan aman dan mengikuti prosedur dan petunjuk kerja yang telah ditentukan.

6.3.1 Persyaratan tugas tertentu termasuk persyaratan kesehatan diidentifikasi dan dipakai untuk menyeleksi dan menempatkan tenaga kerja.

6.3.2 Penugasan pekerjaan harus berdasarkan kemampuan dan keterampilan serta kewenangan yang dimiliki.

6.4.1 Pengusaha atau pengurus melakukan penilaian risiko lingkungan kerja untuk mengetahui daerah-daerah yang memerlukan pembatasan izin masuk.

6.4.2 Terdapat pengendalian atas daerah/tempat dengan pembatasan izin masuk.

6.4.3 Tersedianya fasilitas dan layanan di tempat kerja sesuai dengan standar dan pedoman teknis.

6.5.8 Apabila diperlukan dilakukan penerapan sistem penguncian pengoperasian (lock out system) untuk mencegah agar sarana produksi tidak dihidupkan sebelum saatnya.

6.7.6 Peralatan, dan sistem tanda bahaya keadaan darurat disediakan, diperiksa, diuji dan dipelihara secara berkala sesuai dengan peraturan perundang-undangan, standar dan pedoman teknis yang relevan.

\section{Kriteria yang tidak sesuai}

6.1.1 Petugas yang kompeten telah mengidentifikasi bahaya, menilai dan mengendalikan risiko yang timbul dari suatu proses kerja.

6.1.5 Terdapat sistem izin kerja untuk tugas berisiko tinggi.

6.1.7 Alat pelindung diri yang digunakan dipastikan telah dinyatakan layak pakai sesuai dengan standar dan/atau peraturan perundang-undangan yang berlaku.

6.4.4 Rambu-rambu K3 harus dipasang sesuai dengan standar dan pedoman teknis.

6.5.2 Semua catatan yang memuat data secara rinci dari kegiatan pemeriksaan, pemeliharaan, perbaikan dan perubahan yang dilakukan atas sarana dan peralatan produksi harus disimpan dan dipelihara.

6.5.3 Sarana dan peralatan produksi memiliki sertifikat yang masih berlaku sesuai dengan persyaratan peraturan perundangundangan dan standar.

6.5.4 Pemeriksaan, pemeliharaan, perawatan, perbaikan dan setiap perubahan harus dilakukan petugas yang kompeten dan berwenang.

6.5.7 Terdapat sistem untuk penandaan bagi peralatan yang sudah tidak aman lagi untuk digunakan atau sudah tidak digunakan.

6.5.9 Terdapat prosedur yang dapat menjamin keselamatan dan kesehatan tenaga kerja atau orang lain yang berada didekat sarana dan peralatan produksi pada saat proses pemeriksaan, pemeliharaan, perbaikan dan perubahan.

6.7.4 Petugas penanganan keadaan darurat ditetapkan dan diberikan pelatihan khusus serta diinformasikan kepada seluruh orang yang ada di tempat kerja.

6.8.1 Perusahaan telah mengevaluasi alat P3K dan menjamin bahwa sistem P3K yang ada memenuhi peraturan perundang-undangan, standar dan pedoman teknis.

6.8.2 Petugas P3K telah dilatih dan ditunjuk sesuai dengan peraturan perundanganundangan.

\section{Pembahasan}

1. Pelatihan tentang penggunaan APD belum di lakukan secara teratur. Sebaiknya pelatihan tentang penggunaan APD dan pentingnnya penggunaan APD di lakukan rutin, karena dari data kecelakaan yang terjadi kemungkinan karena pekerja tidak mengindahkan kelengkapan APD pada saat bekerja.

2. Belum di dokumentasikannya seluruh prosedur kerja dan belum diterapkannya suatu sistem ijin kerja untuk tugas tugas yang beresiko tinggi. Sebaiknya perusahaan mendokumentasikan prosedur kerja dan menerapakan ijin kerja terhadap pekerja dengan pekerjaan yang beresiko tinggi, agar hak hak dari pegawai tersebut bisa di pertanggung jawabkan.

3. Kurangnya kepatuhan terhadap peraturan yang terbukti dengan ditemukannya beberapa pekerja yang tidak memakai APD secara lengkap sesuai dengan prosedur. Sebaiknya perusahaan lebih tegas dalam menindaklanjuti kelalaian pekerja dalam menggunakan APD agar pekerja bisaa lebih disiplin dan sadar akan pentingnya kelengkapan APD.

g. Standar Pemantauan

Dari hasil penilaian melalui checklist yang telah disesuaikan dengan PP. No. 50 taun 2012, maka pada kriteria Standar Pemantauan yang terdiri dari 9 kriteria 1 diantaranya sudah memenuhi syarat penilaian yang dilakukan, dalam penilaian ini PT. Muara Kayu Sengon masuk dalam kategori kurang dengan hasil 11,11 \%.

Perusahaan PT. Muara Kayu Sengon belum melakukan Standar Pemantauan Kualitas Tempat Kerja yang sesuai dengan peraturan yang berlaku yaitu PP No. 50 Tahun 2012.

\section{Kriteria yang sesuai}


7.1.1 Pemeriksaan/inspeksi terhadap tempat kerja dan cara kerja dilaksanakan secara teratur.

Kriteria yang tidak sesuai

7.2.1 Pemantauan/pengukuran lingkungan kerja dilaksanakan secara teratur dan hasilnya didokumentasikan, dipelihara dan digunakan untuk penilaian dan pengendalian risiko.

7.2.2 Pemantauan/pengukuran lingkungan kerja meliputi faktor fisik, kimia, biologi, ergonomi dan psikologi.

7.2.3 Pemantauan/pengukuran lingkungan kerja dilakukan oleh petugas atau pihak yang berkompeten dan berwenang dari dalam dan/atau luar perusahaan.

7.4.1 Dilakukan pemantauan kesehatan tenaga kerja yang bekerja pada tempat kerja yang mengandung potensi bahaya tinggi sesuai dengan peraturan perundang-undangan.

7.4.2 Pengusaha atau pengurus telah melaksanakan identifikasi keadaan dimana pemeriksaan kesehatan tenaga kerja perlu dilakukan dan telah melaksanakan sistem untuk membantu pemeriksaan ini.

7.4.3 Pemeriksaan kesehatan tenaga kerja dilakukan oleh dokter pemeriksa yang ditunjuk sesuai peraturan perundangundangan.

7.4.4 Perusahaan menyediakan pelayanan kesehatan kerja sesuai peraturan perundang-undangan.

7.4.5 Catatan mengenai pemantauan kesehatan tenaga kerja dibuat sesuai dengan peraturan perundang-undangan.

\section{Pembahasan}

Perusahaan belum melakukan standar pemantauan yang jelas di atur dalam PP No. 50 Tahun 2012 karena perusahaan tidak memiliki ahli k3. Sebaiknya perusahaan melakukan standar pemantauan yang dapat bekerja sama dengan Labkesmas untuk melakukan standar pemantauan di dalam perusahaan.

h. Pelaporan dan Perbaikan Kekurangan

Dari hasil penilaian melalui checklist yang telah disesuaikan dengan PP. No. 50 taun 2012, maka pada kriteria Pelaporan dan Perbaikan Kekurangan yang terdiri dari 1 kriteria dan belum memenuhi syarat penilaian yang dilakukan,dalam penilaian ini PT. Muara Kayu Sengon masuk dalam kategori kurang dengan hasil $0 \%$.

Perusahaan belum menerapkan keseluruhan kriteria yang terdapat pada PP No. 50 Tahun 2012, hanya ada pelaporan apabila ada kecelakaan kerja dari pekerja ke atasan.

Kriteria yang sesuai

Tidak ada kriteria yang sesuai

Kriteria yang tidak sesuai
8.3.1 Tempat kerja/perusahaan mempunyai prosedur pemeriksaan dan pengkajian kecelakaan kerja dan penyakit akibat kerja.

\section{Pembahasan}

1. Belum terdapat prosedur penanganan masalah keselamatan kerja yang sesuai. Sebaiknya perusahaan memiliki ahli K3 yang memahami prosedur tentang penanganan masalah K3.

2. Penyebaran informasi tentang penanganan keselamatan dan kesehatan kerja tidak diberikan secara rutin kepada tenaga kerja. Sebaiknya perusahaan memberikan informasi kepada semua karyawan, bisa dalam bentuk gambar atau simulasi.

i. Penerapan Pengelolaan Material dan Perpindahanya

Dari hasil penilaian melalui checklist yang telah disesuaikan dengan PP. No. 50 taun 2012, maka pada kriteria Penerapan Pengelolaan Material dan Perpindahanya yang terdiri dari 8 kriteria 1 diantaranya sudah memenuhi syarat penilaian yang dilakukan,dalam penilaian ini PT. Muara Kayu Sengon masuk dalam kategori kurang dengan hasil 12,5\%.

Perusahan belum melakukan semua kriteria yang ada tetapi sudah ada kriteria yang dilakukan oleh perusahaan yaitu :

Pengaturan dan pemantauan kegiatan bongkar muat yang berasal dari eluar masuknya truk pengangkut log dan bahan jadi telah di lakukan dengan pengaturan lalu lintas dengan penyediaan tempat bongkar muat dan, pengaturan jam pengangkutan, pembatasan kecepatan kendaraan, penempatan petugas pengatur lalu lintas, dan adanya pembatas kendaraan di sesuaikan dengan jalan yang di lewati serta adanya perbaikan sarana dan prasarana jalan yang rusak.

Limbah Padat

1. Proses penerimaan log terjadi penumpukaan limbah padat berupa log afkir di area penerimaan log, log afkir yang tidak memenuhi standar akan di kembalikan supplier.

2. Proses pemotongan log berupa sisa potongan log, serbuk, gergaji, dust digunakan untuk bahan bakar mesin.

3. Proses pembuatan barecore dan laminating berupa potongan tepi, sisa kupasan dan sisa potongan dimanfaatkan pabrik untuk bahan bakar mesin.

4. Sisa pemotongan juga ada yang di bakar.

Kriteria yang sesuai

9.3.4 Rambu peringatan bahaya terpasang sesuai dengan persyaratan peraturan perundangundangan dan/atau standar yang relevan.

\section{Kriteria yang tidak sesuai}

9.1.1 Terdapat prosedur untuk mengidentifikasi potensi bahaya dan menilai risiko yang 
berhubungan dengan penanganan secara manual dan mekanis.

9.1.2 Identifikasi bahaya dan penilaian risiko dilaksanakan oleh petugas yang berkompeten dan berwenang.

9.2.1 Terdapat prosedur yang menjamin bahwa bahan disimpan dan dipindahkan dengan cara yang aman sesuai dengan peraturan perundang-undangan.

9.2.3 Terdapat prosedur yang menjamin bahwa bahan dibuang dengan cara yang aman sesuai dengan peraturan perundangundangan.

9.3.1 Perusahaan telah mendokumentasikan dan menerapkan prosedur mengenai penyimpanan, penanganan dan pemindahan BKB sesuai dengan persyaratan peraturan perundangundangan, standar dan pedoman teknis yang relevan.

9.3.2 Terdapat Lembar Data Keselamatan BKB (Material Safety Data Sheets) meliputi keterangan mengenai keselamatan bahan sebagaimana diatur pada peraturan perundang-undangan dan dengan mudah dapat diperoleh.

9.3.3 Terdapat sistem untuk mengidentifikasi dan pemberian label secara jelas pada bahan kimia berbahaya.

\section{Pembahasan}

1. Belum ada prosedur penanganan bahan secara manual atau mekanis pada perusahaan. Sebaiknya dilakukan prosedur penanganan bahan agar dapat meminimalisir kecelakaan kerja atau penyakit akibat kerja.

2. Belum terdapat prosedur pengangkutan, penyimpanan dan pembuangan bahan yang dapat rusak atau kadaluarsa dan proosedur pembuangan bahan yang sesuai dengan peraturan perundang-undangan. Sebaiknya dilakukan prosedur penanganan bahan agar menjadikan kesesuaian dengan peraturanperundang undangan.

3. Belum ada pengendalian tentang bahaya bahan kimia yang terdapat di perusahaan, tetapi sudah di beri peringatan berupa rambu rambu yang tertempel di dinding. Sebaiknya dilakukan pengendalian terhadap bahaya bahan kimia yang terdapat di perusahaan.

j. Pengumpulan dan Peggunaan Data

Kriteria pengumpulan dan penggunaan data tidak termasuk dalam penilaian kriteria yang di tentukan.

Perusahaan belum melakukan Pengumpulan \& Penggunaan Data dalam bidang K3 yang sesuai dengan PP No. 50 Tahun 2012.

Tidak ada kriteria untuk elemen Pengumpulan \& Penggunann data.

Pembahasan
1. Belum adanya pengurus bidang $\mathrm{k} 3$ yang mendokumentasikan dan menerapkan prosedur pelaksanaan identifikasi, pengumpulan, pengarsipan, pemeliharaan, penggantian, dan penggantian catatan k3. Sebaiknya diadakannya pengurus k3 yang mengurus tentang prosedur pelaksanaan identifikasi, pengumpulan, pengarsipan, pemeliharaan, penggantian, dan penggantian catatan k3 di dalam perusahaan.

2. Belum adanya laporan rutin kinerja k3 yang dibuat dan di sebarluaskan di dalam tempat kerja. Sebaiknya pembuatan laporan rutin k3 di laksanakan dan penyebarluasan laporan kinerja k3 kepada karyawan yang ada di perusahaan.

k. Penerapan Audit SMK3

Kriteria penerapan Audit SMK3 tidak termasuk kedalam penilaian yang di tentukan.

Perusahaan belum menerapkan dan melakukan Audit SMK3 sesuai dengan PP No. 50 Tahun 2012, tetapi sudah ada rencana untuk menerapkannya.

Tidak ada kriteria untuk elemen Pengumpulan \& Penggunann data.

\section{Pembahasan}

Permasalahan yang ditemukan adalah belum terlaksana Audit SMK3 yang dlaksanakan oleh ahli k3 yang berkompeten untuk memeriksa kesesuaian kegiatan perancanaan dan untuk menentukan efektifitas kegiatan yang dilakukan di dalam perusahaan. Sebaiknya perusahaan mempekerjakan ahi k3 yang berkompeten untuk memeriksa memeriksa kesesuaian kegiatan perancanaan dan untuk menentukan efektifitas kegiatan yang dilakukan di dalam perusahaan agar semua kegiatan yang dilaksanakan jelas dan terarah.

1. Pengembangan Ketrampilan dan Kemampuan

Dari hasil penilaian melalui checklist yang telah disesuaikan dengan PP. No. 50 taun 2012, maka pada kriteria Pengembangan Ketrampilan dan Kemampuan yang terdiri dari 3 kriteria 1 diantaranya sudah memenuhi syarat penilaian yang dilakukan,dalam penilaian ini PT. Muara Kayu Sengon masuk dalam kategori kurang dengan hasil 14,28\%

Pelatihan karyawan di PT. Muara Kayu Sengon adalah sebagai berikut :

1. Pelatihan yang mencakup penggunaan APD kepada karyawan, namun program pelatihan tersebut belum sepenuhnya di lakukan secara maksimal, terbukti dengan ditemukannya beberapa dari pekerja yang tidak menggunakan APD sesuai dengan prosedur yang telah ditetapkan.

2. Pelatihan tanggap darurat, dalam program pelatihan yang di rencanakan PT. Muara Kayu Sengon terdapat program pelatihan tanggap darurat, namun program tersebut 
hanya di lakukan setelah terjadinya bencana atau kecelakaan kerja

3. Pelatihan yang di lakukan disesuaikan dengan tingkat kemampuan, keahlian dan kepentingannya.

4. Belum dilakukan program peninjauan ulang secara berkala agar senantiasa relevan dan efektif.

\section{Kriteria yang sesuai}

12.3.1 Pelatihan diberikan kepada semua tenaga kerja termasuk tenaga kerja baru dan yang dipindahkan agar mereka dapat melaksanakan tugasnya secara aman.

\section{Kriteria yang tidak sesuai}

12.2.1 Anggota manajemen eksekutif dan pengurus berperan serta dalam pelatihan yang mencakup penjelasan tentang kewajiban hukum dan prinsip-prinsip serta pelaksanaan K3.

12.5.1 Perusahaan mempunyai sistem yang menjamin kepatuhan terhadap persyaratan lisensi atau kualifikasi yang sesuai.

\section{Pembahasan}

1. Belum dilaksanakannya analisis mengenai kebutuhan pelatihan yang mencakup keselamatan dan kesehatan kerja dan belum dilakukannya peninjauan terhadap efektifitas pelatihan tersebut. Sebaiknya perusahaan melakukan analisa terhadap kebutuhan pelatihan terhadap pekerja agar pekerja lebih kompeten, dan melakukan peninjauan apakah hasil dari pelatihan tersebut berjalan dengan efektif.

2. Perusahaan belum mendokumentasikan dan menyimpan seluruh catatan pelatihan. Sebaiknya perusahaan mengadakan pelatihan secara rutin dan terjadwalkan untuk kemudian bisa didokumentasikan.

\section{IV.KESIMPULAN}

Dari hasil pengisian checklist yang mengacu kepada PP No. 50 tahun 2012 dengan 64 kriteria yang ada di PT. Muara Kayu Sengon termasuk kedalam kategori kurang dengan hasil penilaian sebesar 23,43\%, dengan rincian dari hasil 12 elemen SMK3 yang kesimpulannya sebagai berikut

a. Pada kriteria Pembangunan dan Pemeliharaan Komitmen yang terdiri dari 14 kriteria 2 diantaranya sudah memenuhi syarat penilaian yang dilakukan, dalam penilaian ini PT. Muara Kayu Sengon masuk dalam kategori kurang dengan hasil 14,28\%.

b. Pada kriteria Pembuatan dan Pendokumentasian Rencana K3 yang terdiri dari 2 dan belum ada yang memenuhi syarat penilaian yang dilakukan, dalam penilaian ini PT. Muara Kayu Sengon masuk dalam kategori kurang dengan hasil $0 \%$

c. Pada kriteria Peninjauan Ulang Desain dan K3 yang terdiri dari 2 kriteria dan belum ada yang memenuhi syarat penilaian, dalam penilaian ini
PT. Muara Kayu Sengon masuk dalam kategori kurang dengan hasil $0 \%$

d. Pada kriteria Pengendalian Dokumen K3 yang terdiri dari 1 kriteria dan belum ada yang memenuhi syarat penilaian yang dilakukan, dalam penilaian ini PT. Muara Kayu Sengon masuk dalam kategori kurang dengan hasil $0 \%$

e. Pada kriteria Pembelian yang terdiri dari 2 kriteria, 2 kriteria tersebut sudah memenuhi syarat penilaian yang dilakukan, dalam penilaian ini PT. Muara Kayu Sengon masuk dalam kategori baik dengan hasil $100 \%$.

f. Pada kriteria Penerapan Keamanan Bekerja Berdasarkan SMK3 yang terdiri dari 22 kriteria, 8 diantaranya sudah memenuhi syarat penilaian tersebut, dalam penilaian ini PT. Muara Kayu Sengon masuk kategori kurang dengan hasil 36,36 $\%$.

g. Pada kriteria Standar Pemantauan yang terdiri dari 9 kriteria 1 diantaranya sudah memenuhi syarat penilaian yang dilakukan, dalam penilaian ini PT. Muara Kayu Sengon masuk dalam kategori kurang dengan hasil 11,11\%.

h. Pada kriteria Pelaporan dan Perbaikan Kekurangan yang terdiri dari 1 kriteria dan belum memenuhi syarat penilaian yang dilakukan,dalam penilaian ini PT. Muara Kayu Sengon masuk dalam kategori kurang dengan hasil 0 \%.

i. Pada kriteria Penerapan Pengelolaan Material dan Perpindahanya yang terdiri dari 6 kriteria 1 diantaranya sudah memenuhi syarat penilaian yang dilakukan,dalam penilaian ini PT. Muara Kayu Sengon masuk dalam kategori kurang dengan hasil 16,67 \%.

j. Pada kriteria Pengumpulan dan Penggunaan Data tidak dilakukan penilaian karena tidak termasuk ke dalam penilaian.

k. Pada kriteria Penerapan Audit SMK3 tidak dilakukan penilaian karena tidak termasuk ke dalam penilaian.

l. Pada kriteria Pengembangan Ketrampilan dan Kemampuan yang terdiri dari 14 kriteria 2 diantaranya sudah memenuhi syarat penilaian yang dilakukan,dalam penilaian ini PT. Muara Kayu Sengon masuk kategori kurang dengan hasil $14,28 \%$

\section{DAFTAR PUSTAKA}

Profil PT. Muara Kayu Sengon (MKS) tahun 2014.

Struktur Organisasi PT. Muara Kayu Sengon (MKS)

Ahmad Hidayat, Andrian, 2013, Studi Penerapan Keselamatan Dan Kesehatan Kerja Pada Bagian Produksi PT dharmapala Usaha Sukses Cilacap tahun. 
Anonim, 2012, PeraturanPemerintah Nomor50 tahun2012, diakses tanggal 5 Januari 2016, jam 20.00 WIB

Anonim, 2012, Audit Checklist Sistem Manajemen Keselamatan dan Kesehatan Kerja.

Anonim,http://www.academia.edu/11671845/SISTE M_MANAJEMEN_K3_KESELAMATAN_D AN_KESEHATAN_KERJA_

Badawi, Maulana, 2013, Studi Penerapan Sistem Manajemen Keselamatan dan Kesehatan Kerja di PT Royal KorindahKabupaten Purbalingga.
Rudityanto, 2003. Sistem Manajemen Keselamatan Dan Kesehatan Kerja (SMK3) dan Audit SMK3. Prosiding seminar nasional keselamatan dan kesehatan kerja, yogyakarta, 20 September 2003

Suardi, Rudi, 2005. Sistem Manajemen Keselamatan dan Kesehatan Kerja. Jakarta : PPM

Suma’mur, P. M.,M.Sc, 1986. Kecelakaan Kerja dan Pencegahan Kecelakaan. Haji Masagung, Jakarta. 